\title{
MEREDUKSI KECANDUAN GAME ONLINE MELALUI LAYANAN KONSELING DENGAN TEKNIK KONTRAK PERILAKU PADA SISWA XI RPL SMK NEGERI 1 LUMAJANG TAHUN AJARAN 2018/2019
}

\author{
Fitrah Romadhoni Laily \\ SMK Negeri 1 Lumajang \\ fitra.rl@gmail.com \\ Etik Sulistiyowati \\ SMKN 1 Jetis Mojokerto \\ etik.sulis@gmail.com
}

\begin{abstract}
Abstrak
Kecanduan game online adalah perilaku yang bersifat kronis dan kompulsif untuk memuaskan diri pada permainan yang dimainkan dengan koneksi internet hingga menimbulkan masalah dalam kehidupan sehari-hari. Permasalahan yang timbul sifatnya merugikan diri sendiri, meskipun demikian tidak membuat pemain berusaha untuk menghentikan atau mengurangi aktivitasnya bermain game online karena merasa sulit untuk keluar atau berhenti memainkan game online (Pratiwi dkk, 2012:3). Jadi, bagi para pecandu game online akan sulit untuk mengontrol atau mengendalikan dirinya dan berhenti atau setidaknya mengurangi waktu dan kuantitas bermain game onlinenya. Untuk memperbaiki kondisi kecanduan Game Online, Guru BK memberikan layanan konseling individu dengan teknik kontrak perilaku diharapkan dapat menjadi solusi permasalahan kecanduan Game Online. Pada proses konseling diharapkan konseli akan lebih terbuka untuk menceritakan masalahnya yang mungkin berkaitan dengan penyebab munculnya perilaku bermasalah. Upaya dalam mengubah perilaku dalam konseling individu ini dengan tehnik kontrak perilaku (behaviour contract). Subjek dalam penelitian ini adalah konseli di SMK Negeri 1 Lumajang kelas XI RPL dengan karakteristik konseli bermasalah dalam kecanduan game online sehingga tidak mengikuti pembelajaran daring dan nilai menjadi kosong sehingga konseli memiliki ketakutan terhadap guru pengajar dan kejengkelan kepada ibu dikarenakan ibu marah dengan aktifitas konseli. Hasil penelitian ini menunjukkan ketercapaian mereduksi kecanduan game online melalui konseling individu dengan strategi kontrak perilaku yaitu hasil angket kecanduan game online pada konseli mengalami perkembangan yang signifikan pretest siklus 1 , posttest siklus 1 dan posttest siklus 2 menunjukkan perkembangan hasil skor yang meningkat pada setiap siklusnya yaitu 55 kategori Tinggi ; 46 kategori Tinggi dan ; 24 Kategori Sedang.
\end{abstract}

Kata Kunci: Konseling Kelompok teknik Kontrak Perilaku dan Kecanduan Game Online

\begin{abstract}
Online game addiction is a chronic compulsive behavior to indulge in games played with an internet connection, causing problems in someone's life. Problems that arise are harmful, and even so they do not make players try to stop or reduce their activities playing online games because they find it difficult to leave or stop playing online games (Pratiwi et al, 2012: 3). So, for online game addicts it will be difficult to control themselves and stop, or at least reduce the frequency of playing online games. To improve the condition of Online Game addiction, the Counseling Teacher provides individual counseling services with the behavioral contract technique which is expected to be a solution to the problem of Online Game addiction. In the counseling process, it is hoped that the counselee will be more open to telling problems that
\end{abstract}


may be related to the causes of problematic behavior. Efforts to change behavior in individual counseling employed the behavior contract technique. The subjects in this study were counselees at SMK Negeri 1 Lumajang class XI RPL with the characteristics of the counselee having problems with online game addiction so that they did not participate in online learning with zero scores so that the counselee had a fear to the teachers and afraid of their mothers because their mothers were angry with the counselee's activity. The results of this study indicate the achievement of reducing online game addiction through individual counseling with a behavioral contract strategy, namely the results of the online game addiction questionnaire on the counselee experienced a significant development in the pretest cycle 1, posttest cycle 1 and posttest cycle 2 showed that the progress of the score results increased in each cycle, namely 55 High category; 46 categories High and; 24 Medium Category.

Keywords: Counseling behavioral contract, online game addiction

\section{LATAR BELAKANG}

Game online merupakan sebuah wujud perkembangan teknologi pada saat ini. Game online merupakan jenis permainan yang dapat diakses dan dimainkankan oleh satu atau lebih pengguna internet. Hampir semua orang sudah pernah mengakses game online. Pada 2013, American Psychological Association (APA) melakukan riset tentang bagaimana game bisa digunakan sebagai alat edukasi serta dampak positif game pada anak dan remaja, bermain game dapat meningkatkan kemampuan kognitif anak, termasuk spatial navigation, persepsi, daya ingat, sampai pemikiran kritis.

Selain berbagai dampak positif yang dimiliki oleh internet, terdapat beberapa dampak negatif dari internet, terutama yang berkaitan dengan Game Online. Dampak negatif tersebut diantara adalah kecanduan. WHO sebagai badan resmi kesehatan dunia telah menggolongkan kecanduan game online sebagai gangguan kejiwaan. Game online telah mempengaruhi gaya hidup seseorang. Game online mengakibatkan perubahan gaya hidup. Kecanduan game online adalah perilaku yang bersifat kronis dan kompulsif untuk memuaskan diri pada permainan yang dimainkan dengan koneksi internet hingga menimbulkan masalah dalam kehidupan sehari-hari. Permasalahan yang timbul sifatnya merugikan diri sendiri, meskipun demikian tidak membuat pemain berusaha untuk menghentikan atau mengurangi aktivitasnya bermain game online karena merasa sulit untuk keluar atau berhenti memainkan game online (Pratiwi dkk, 2012:3).

Permasalahan yang terjadi di SMK Negeri 1 Lumajang, yang berkaitan dengan game online adalah adanya beberapa peserta didik yang tidak dapat mengikuti pembelajaran dan tidak mampu mampu menyelesaikan tugas-tugas yang diberikan oleh ibu/bapak guru. Game online menyebabkan peserta didik menjadi banyak kehilangan waktu belajar dan terlalu senang bermain game online. Untuk memperbaiki kondisi kecanduan Game Online, Guru BK memberikan layanan konseling individu dengan teknik kontrak perilaku diharapkan dapat menjadi solusi permasalahan kecanduan Game Online. Berdasarkan penjabaran di atas maka peneliti tertarik untuk melakukan penelitian tentang pemberian layanan konseling kontrak perilaku dalam mereduksi kecanduan game online pada peserta didik kelas XI RPL SMK Negeri 1 Lumajang.

\section{METODE}

Untuk pendekatan penelitian, peneliti menggunakan Penilitian Tindakan Kelas (PTK). Pengertian penelitian tindakan kelas berasal dari istilah bahasa Inggris Classroom Action Research, yang berarti penelitian yang dilakukan pada sebuah kelas untuk mengetahui akibat tindakan yang diterapkan pada suatu subyek penelitian di kelas tersebut. Pertama 
kali penelitian tindakan kelas diperkenalkan oleh Kurt Lewin pada tahun 1946, yang selanjutnya dikembangkan oleh Stephen Kemmis, Robin Mc Taggart, John Elliot, Dave Ebbutt dan lainnya. PTBK adalah sebuah kegiatan penelitian untuk memberikan tindakan yang dilakukan dalam lingkup bimbingan dan konseling.

Subjek penelitian ini adalah peserta didik kelas XI RPL SMK Negeri 1 Lumajang berjumlah 1 peserta didik yang memiliki mengalami kecanduan game online kategori tinggi. Penelitian Tindakan Bimbingan dan Konseling ini dilakukan di ruangan konseling yang disediakan oleh guru Bimbingan Konseling. Penelitian Tindakan Bimbingan dan Konseling ini dilakukan dengan menggunakan 2 siklus. Menurut Kemmis dan McTaggart (1990) penelitian tindakan pada hakikatnya berupa rangkaian kegiatan yang terdiri dari empat langkah, yaitu perencanaan, tindakan, pengamatan, dan refleksi. Keempat langkah tersebut merupakan serangkaian sebagai satu siklus penelitian tindakan. Desain penelitian adalah sebagai berikut:

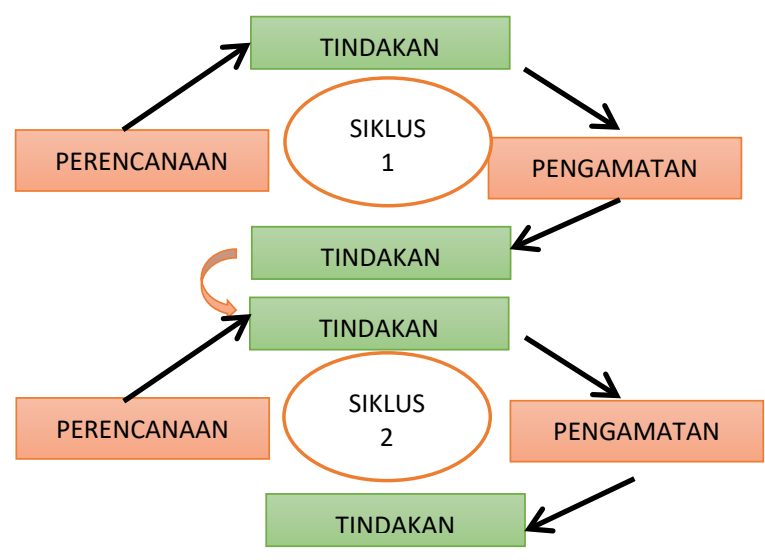

Metode yang digunakan dalam penelitian ini adalah pretest dan postest skala kecanduan game online, pedoman observasi dan evaluasi hasil. Penelitian ini menggunakan skala kecanduan game online untuk mengukur sejauh mana perubahan peserta didik terkait dengan kecanduan game online yang dialaminya. Pedoman observasi digunakan untuk mengukur keefektifan konseling individu teknik kontrak perilaku dalam mereduksi kecanduan game online, sedangkan evaluasi hasil digunakan untuk mengukur keberhasilan konseling individu. Skala diberikan sebelum pelaksanaan konseling individu untuk mengukur kecanduan game online pada peserta didik. Setelah pelaksanaan konseling individu kontrak perilaku siklus 1 untuk mengetahui perbandingan tingkat kecanduan game online setelah pelaksanaan diskusi siklus 2 untuk mengetahui penurunan kecanduan game online peserta didik. Penelitian ini menggunakan angket kecanduan game online yang terdiri dari 15 pernyataan. Skala yang disusun dalam penelitian ini menggunakan empat alternatif jawaban, yaitu: sangat sering dengan skor 4, Sering dengan skor 3, Kadang-kadang dengan skor 2 dan Tidak Pernah dengan skor 1. Perhitungan skor adalah Skor Total dengan menjumlahkan jumlah semua skor. Kritria skor dari angket sebagai berikut: Skor Tinggi $=46-60$, skor Rendah $=16-45$ dan Skor Ringan $=0-15$. Pedoman observasi keterlaksanaan layanan konseling individu menggunakan instrumen asesmen proses yang terdiri dari 25 item. Pedoman penskoran adalah bila dijawab YA mendapat skor 4, bila dijawab TIDAK mendapat skor 0 . Penghitungan skor $4 \mathrm{x}$ item dengan jawaban YA. Kriteria skor adalah skor 25-43 = kurang, 44-62= sedang, skor 63-81 = baik dan skor 82-100 = sangat baik.

Pedoman observasi keefektifan konseling individu menggunakan instrument asesmen hasil. Instrumen asesmen hasil terdiri dari 10 aitem pernyataan. Pedoman penskoran menggunakan jawaban iya skor 1 dan tidak skor 0. Penghitungan skor adalah Skor total = menjumlah semua jawaban iya. Kriteria skor adalah $0-3=$ cukup baik, 5-7 = baik dan $8-10=$ sangat baik.

\section{HASIL PENELITIAN}

Hasil yang diperoleh pada siklus 1 adalah sebagai berikut: perhitungan skor kecanduan game online pretest $=55$ 
termasuk dalam katergori tinggi, pada keterlaksanan konseling individu dengan skor 32 termasuk kategori cukup baik dan respon yang diberikan peserta didik terhadap keefektifan konseling individu masih dalam taraf rendah dengan skor 3 . Hasil refleksi peneliti adalah belum ada ketercapaian dalam memberikan konseling individu dikarenakan kurang tajam dalam mengidentifikasi masalah, ketidaksiapan konselor dalam memberikan layanan sehingga ada beberapa tahapan konseling yang terlewati. Berdasarkan paparan di atas terdapat beberapa kelemahan pada saat pelaksanaan konseling individu. Kelemahan tersebut akan dijadikan perbaikan pada siklus II.

Hasil yang diperoleh pada siklus 2 adalah sebagai berikut: menunjukkan perkembangan yang signifikan peserta didik mengalami banyak perubahan perilaku dalam mereduksi kecanduan game online dari skor 46 menjadi skor 24, keterlaksanaan konseling individu adalah skor 68 yang berrati termasuk dalam ketegori "baik".menunjukkan hasil bahwa melalui konseling individu dengan teknik kontrak perilaku dapat mereduksi kecandun game online.

Berdasarkan paparan di atas terdapat beberapa kelemahan pada saat pelaksanaan konseling individu. Kelemahan adalah konseli belum terbuka dalam mengidentifikasi permasalahannya. Sikap konselor masih terlihat kaku dan tegang sehingga hasil yang didapatkan masih belum maksimal, namun sudah memberi jawaban atas tujuan dari penelitian tindakan bimbingan dan konseling ini.

\section{PEMBAHASAN}

Berdasarkan tindakan pada siklus 1, belum memberikan hasil yang berarti karena guru selaku konselor dalam pemberian konseling individu pada tahapan inti masih banyak yang terlewati begitu pula dalam memberikan penjelasan tentang mengimplementasikan kontrak perilaku hanya dijelaskan dengan menggunkan metode ceramah sehingga terkesan tidak menarik dan konselor masih terlihat kaku dalam memberikan konseling individu. Maka data pada skor penilaian observasi terhadap keterlaksanaan konseling pada siklus 1 adalah 32 dengan predikat cukup baik.

Konseling individu siklus 2, konselor sudah mengoptimalkan tahapantahapan konseling individu teknikkontrak perilaku, konselor menayangkan, menjelaskan dan membimbing konseli dalam mengimplementasikan kontrak perilaku sekaligus memberi tugas kepada konseli untuk menyusun jadwal kegiataan sehari-hari sebagai pedoman atau acuan konseli dalam melaksanakan kegiatan sehari-hari. Maka hasil skor penilaian observasi keterlaksanaan pada siklus 1 adalah 32 kategori cukup baik dan pada siklus 2 menjadi skor 68 kategori baik. Hasil angket kecanduan game online pada konseli mengalami perkembangan yang signifikan pretest siklus 1 , posttest siklus 1 dan posttest siklus 2 menunjukkan perkembangan hasil skor yang meningkat pada setiap siklusnya yaitu 55 kategori Tinggi ; 46 kategori Tinggi dan ; 24 Kategori Sedang.

Data yang diperoleh dari observasi hasil respon konseli ada perubahan perilaku semula penilaian skor pada sikluas 1 adalah 3 dengan kategori rendah dan pada siklus 2 mengalami peningkatan dengan skor 8 kategori tinggi, hal ini berarti mereduksi kecanduan game online melalui konseling individu dengan tehnik kontrak perilaku menunjukkan keberhasilan penelitian tindakan bimbingan dan konseling.

\section{KESIMPULAN DAN SARAN}

Hasil Penelitian Tindakan
Bimbingan dan Konseling ini, menunjukkan bahwa dalam mereduksi kecanduan game online melalui konseling individu dengan teknik kontrak perilaku merupakan langkah efektif yang bisa digunakan oleh konselor. Konseling individu teknik kontrak perilaku memberi 
Jurnal HELPER, Vol 36 No 1 (2019) 16 - 20

Bimbingan dan Konseling Universitas PGRI Adi Buana Surabaya

ISSN: 02162938

kemudahan kepada konseli dalam mengidentifikasi masalah, mengevaluasi penyebab perilaku bermasalah, dan menyusun strategi dalam mengatasi masalah serta menyusun konsekuensi yang akan diberikan ketika konseli mampu mengubah perilaku bermasalah menjadi perilaku yang baru.

Saran bagi teman sejawat atau peneliti selanjutnya adalah, dalam memulai suatu konseling individu perlu mempersiapkan perangkat layanan dengan menyesuaikan kebutuhan konseli. Kedua, lonselor lebih memperhatikan dan mengali faktor-faktor penyebab permasalahan yang terjadi pada konseli, dan yang terakhir berpedoman pada RPL yang telah disusun. Kemudian saran bagi konseli adalah, hendaknya dapat mereduksi kecanduan game online, dengan melakukan kegiatan sesuai dengan kontrak perilaku yang telah disusun dan disepakati oleh konseli dan konselor. Kedua, dengan mengimplematasikan kontrak perilaku, diharapkan konseli bisa mengubah perilaku bermasalah menjadi perilaku tidak bermasalah, sehingga perilaku baru itu menjadi suatu kebiasaan.

\section{DAFTAR RUJUKAN}

Abidin, Zainal. (2009). Optimalisasi Konseling Individu Dan Kelompok Untuk Keberhasilan Siswa. Jurnal Pemikiran Alternatif Pendidikan.

Alberto, P.A \& Troutman, A.C (2009), Aplikasi Analisis Behavioral Untuk Guru, Columbus, OH.

Dictio (2017). Apa yang dimaksud dengan Kontrak Perilaku. Available at https://www.dictio.id/t/apa-yangdimaksud-dengan-kontrakperilaku/124458

Komalasari, Gantina. 2011. Teori dan Teknik Konseling. Jakarta: PT. Indeks

Rahmat Anhar (2014). Skripsi Hubungan kecanduan game online dengan keterampilan sosial remaja di 4 game centre klojen kota Malang. Fakultas Psikologi Universitas Islam Negeri Maulana Malik Ibrahim Malang.

Ratna, Lilis. 2013. Teknik-teknik Konseling. Sleman: Deeplublish. 